\title{
MIASTENIA GRAVIS POST-TIMECTOMIE
}

\author{
C. Motaş ${ }^{\bowtie}$, Natalia Motaş, T. Horvat \\ Clinica de Chirurgie Toracică, Institutul Oncologic „Prof. Dr. Al. Trestioreanu” Bucureşti \\ Universitatea de Medicină şi Farmacie „Carol Davila”, Bucureşti
}

\begin{abstract}
MIASTENIA GRAVIS AFTER THYMECTOMY (Abstract): Although the relationship between myasthenia gravis and thymomas it is well known, with some of myasthenias disappearing after thymectomy, myasthenia may develop after thymoma resection. We present a case of 36 years old man who developed generalized myasthenia 6 years after thymoma surgery; it had been performed tumorectomy, mediastinal fat resection, resection of the anterior wall of left brachiocefalic vein with PTFE patch reconstruction (Masaoka stage III thymoma). After 4 years of corticoid therapy (methylprednisolone) he was operated for steroid cataract. 11 years after resection he is tumor-free and the brachiocefalic vein is functional on CT-scan. Myasthenia after thymectomy is rare but possible after thymoma resection; it is not influenced by association of mediastinal fat resection. The titer of specific auto antibodies and the grade of thymoma invasion are predictive factors for myasthenia development after thymectomy.
\end{abstract}

\section{KEY WORDS: MIASTENIA GRAVIS; THYMOMA; THYMECTOMY}

SHORT TITLE: Miastenia gravis post timectomie

Myasthenia gravis after thymectomy

HOW TO CITE: Motaş C, Motaş N, Horvat T. [Myasthenia gravis after thymectomy]. Jurnalul de chirurgie (Iaşi). 2013; 9(2): 179-184. DOI: 10.7438/1584-9341-9-2-10.

\section{INTRODUCERE}

Miastenia gravis (MG) este o boală autoimună a sinapsei neuromusculare, care se caracterizează printr-o oboseală excesivă a musculaturii striate, ce apare la efort şi se recuperează parțial sau total prin repaus sau sub acțiunea unor substanțe anticolinesterazice. Timoamele sunt tumori maligne care derivă din țesutul epitelial timic.

Atât miastenia cât şi timoamele sunt leziuni rar întâlnite în practica curentă: miastenia gravis apare cu o frecvență anuală de 0,25-2 cazuri/100.000 locuitori [1], în timp ce în cazul timoamelor frecvența anuală este de 0,15 cazuri/100.000 locuitori [2], adică $0,2-1,5 \%$ din totalitatea tumorilor maligne.

Este binecunoscută relația dintre timoame şi miastenia gravis: $10-15 \%$ din miastenii pot coexista cu un timom şi, invers, circa $30 \%$ din timoame pot prezenta ca manifestare paraneoplazică miastenia gravis [3].

Deşi mecanismul fiziopatologic al miasteniei nu este încă bine cunoscut, rolul timusului este însă unanim acceptat. Pe altă parte o manifestare paraneoplazică anunță şi însoțeşte o malignitate şi de multe ori se remite după exereza completă a leziunii tumorale. La prima vedere este paradoxal ca o paraneoplazie, care apare în strânsă legătură cu un organ transformat malign, să apară la multă vreme după ce organul respectiv şi implicit tumora au fost extirpate. Miastenia postoperatorie este definită ca forma de miastenie gravis care apare după rezecția unui timom non-miastenic.

\section{PREZENTARE DE CAZ}

Pacientul D.S., la vârsta de 36 de ani, în 2001, în urma unui examen radiologic de 
rutină, a fost diagnosticat cu o opacitate la nivelul mediastinului. Examenul CT toracic a confirmat existența unei formațiuni tumorale în mediastinul anterior (Fig. 1, 2). Iniţial s-a adresat unui alt serviciu chirurgical toracic unde s-a practicat $\mathrm{o}$ mediastinotomie anterioară. Rezultatul examenului histopatologic al fragmentelor recoltate a fost timom. Ulterior s-a adresat clinicii noastre. Preoperator, pacientul era complet asimptomatic, nefiind evidentiate semne clinice ale miasteniei gravis. $\mathrm{Nu}$ s-au dozat anticorpii antireceptor de acetilcolină şi nu s-au efectuat studii electromiografice.

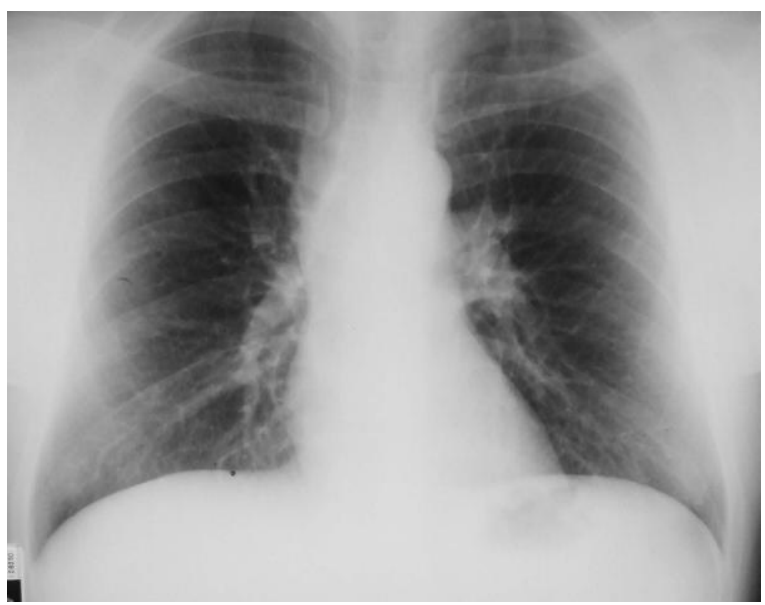

Fig. 1 Radiografie toracică preoperatorie: lărgirea discretă a opacității mediastinale

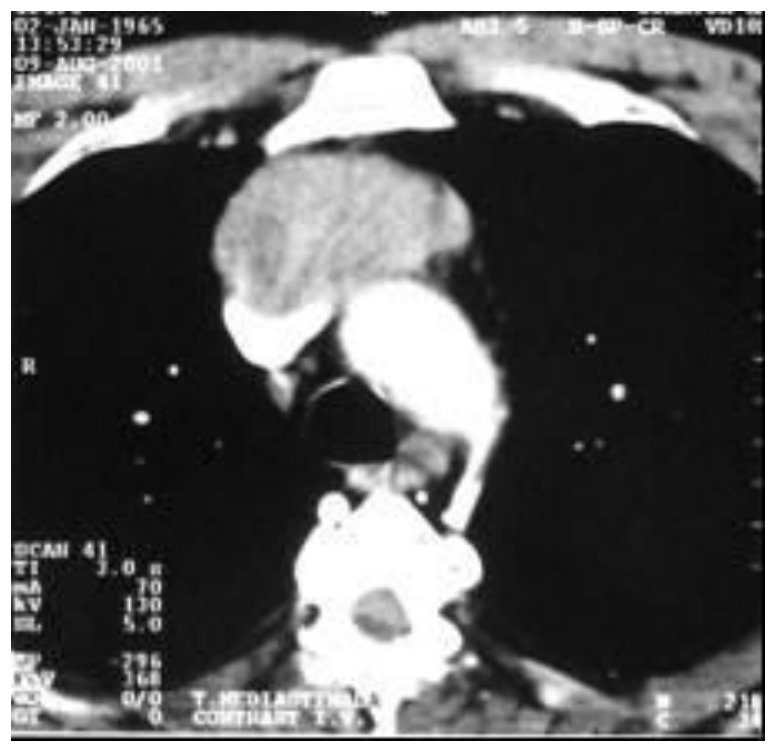

Fig. 2 Computer tomografie toracică cu substanță de contrast: se constată invazia timomului în trunchiul venos brahiocefalic în apropierea vărsării în vena cavă superioară
S-a intervenit chirurgical prin sternotomie mediană totală şi intraoperator s-a decelat o voluminoasă formaţiune tumorală timică ce invada trunchiul venos brahiocefalic stâng (TVBCS) şi ambele pleure mediastinale. S-a practicat rezecția tumorii mediastinale în bloc cu timusul şi întreaga grăsime a mediastinului anterior. A fost necesară rezecția pleurelor mediastinale invadate şi a circa $3 \mathrm{~cm}$ din peretele anterior al trunchiului venos brahiocefalic invadat. Reconstrucția vasculară a fost efectuată cu un petec de PTFE (Poli-Tetra-Fluor-Etilenă). Datorită manevrelor de eliberare a nervului frenic drept din tumoră s-a instalat o pareză tranzitorie a hemidiafragmului drept. Aceasta a fost obiectivată de radiografia postoperatorie şi tradusă clinic prin necesitatea menținerii suportului ventilator pentru primele 48 de ore postoperatorii. Examenul histopatologic al piesei de rezecție a fost de timom tipul AB (conform clasificării OMS) şi, prin confirmarea histopatologică a invaziei vasculare, tumora a fost clasificată ca fiind în stadiul III Masaoka.

Perioada postoperatorie a decurs fără alte incidente, pacientul fiind externat la 11 zile de la intervenție cu recomandarea continuării tratamentului anticoagulant. A urmat tratament adjuvant (radioterapie şi chimioterapie) fiind dispensarizat în rețeaua oncologică. La jumătatea anului 2002 pacientul încheie radioterapia mediastinului şi chimioterapia.

Evoluția în continuare a fost fără incidente pentru ca, după 6 ani, să se instaleze relativ brusc astenia fizică generalizată. Pacientul este diagnosticat cu miastenia gravis grupa III Osserman, boala fiind controlată prin tratament cu anticolinesterazice (mestinon 4 x $60 \mathrm{mg} / \mathrm{zi}$ ) şi antiinflamatoare steroidiene (metilprednisolon). Nivelul seric al anticorpilor antireceptor de acetilcolină au avut valori de 84 nmol/L. După 4 ani de corticoterapie, în 2011, pacientul este operat pentru cataractă cortizonică. Ultimul control CT efectuat în 2010 nu relevă semne de recidivă tumorală sau alte localizări ale leziunii maligne. În 
plus demonstrează permeabilitatea grefei vasculare (Fig. 3).

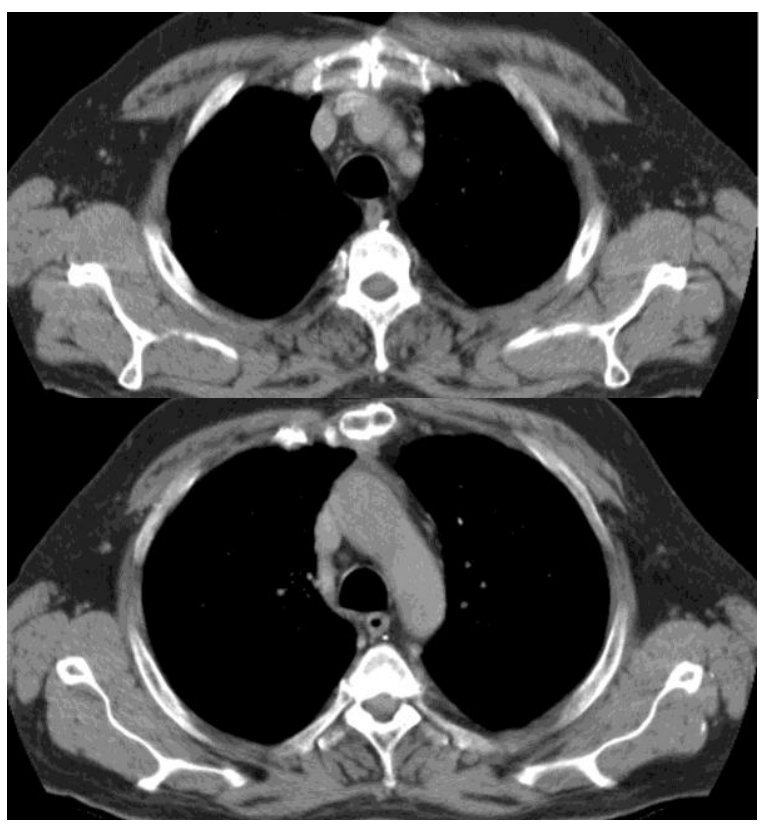

Fig. 3 CT postoperator: absența recidivei tumorale şi permeabilitatea segmentului venos protezat

\section{DISCUȚII}

Miastenia gravis postoperatorie a fost semnalată încă din anii '50, în acel moment considerându-se că aceasta ar fi legată de recidiva tumorală $[4,5]$. Ulterior, majoritatea raportărilor apariției fenomenelor miastenice au fost făcute în special la pacienți fără recidivă tumorală, atât în raportări solitare
$[6,7]$ cât şi în evaluări ale unor grupuri mai mari de studiu [8-10].

În general frecvența apariției acestor manifestări este extrem de redusă, fiind rezultatul combinației a două afecțiuni rare. Exceptând 2 studii care raportează frecvențe de $28 \%$ (7 din 25) [8] şi de 19,8\% (9 din 46) [11] din totalitatea timoamelor rezecate, majoritatea autorilor cifrează posibilitatea apariției acestei complicații la valori cuprinse între 1 şi $11,8 \%$ [3,12-14]. Valorile mari obținute de Namba şi colab. [8] trebuie analizate şi prin prisma lotului analizat: din cei 72 de pacienți cu timom, 47 aveau şi miastenie în momentul operator $(65,2 \%)$, valorile fiind $\mathrm{cu}$ mult mai mari decât raportările generale ale asociației timom miastenie (30\%). De altfel, Namba şi colab. [8], integrând cele 7 cazuri personale cu alte 26 de cazuri din alte studii, găseşte 0 frecvenţă de $3 \%$ a miasteniei posttimomectomie. În Tabelul I sunt prezentate sintetic cele mai reprezentative lucrări cu privire la miastenia postoperatorie.

Majoritatea studiilor nu găsesc corelații între rata apariţiei miasteniei postoperatorii şi forma histologică O.M.S. $[3,8,9,14]$, distribuția pe formele histologice ale timomului rezecat fiind similară cu cea întâlnită în timoamele cu miastenie în momentul operației.

Tabel I Principalele studii referitoare la miastenia gravis post-timectomie

\begin{tabular}{|c|c|c|c|c|}
\hline Studiul & $n^{*}$ & $\Delta \mathrm{t}$ & AAC preoperator** & Recurență \pm metastaze \\
\hline Namba T, 1978 [8] & $\begin{array}{c}7 \operatorname{din} 25 \\
(28 \%)\end{array}$ & 2 săpt. - 6 ani & - & - \\
\hline Ohta I, 1991[11] & $\begin{array}{l}9 \operatorname{din} 46 \\
(19,6 \%)\end{array}$ & 9 zile $-5,8$ ani & $\begin{array}{l}\text { AAC antimusculatură } \\
\text { striată } 9 \text { din } 18(50 \%)\end{array}$ & - \\
\hline Ito M, 1992 [13] & $\begin{array}{c}18 \operatorname{din} 394 \\
(4,6 \%)\end{array}$ & $0-11$ ani & - & $\begin{array}{c}5 \text { recurențe/11 cu } \\
\text { debut }>6 \text { luni }(45,4 \%)\end{array}$ \\
\hline Evoli A, 2002 [10] & $\begin{array}{l}13 \operatorname{din} 207 \\
(6,28 \%)^{* * *}\end{array}$ & 6 luni - 10 ani & - & 3 recurențe $(23 \%)$ \\
\hline Li J, 2004 [14] & $\begin{array}{c}15 \operatorname{din} 127 \\
(11,8 \%)\end{array}$ & $0-137$ luni & - & - \\
\hline Kondo K, 2005 [3] & $\begin{array}{c}8 \operatorname{din} 827 \\
(1 \%)\end{array}$ & 6 zile -45 luni & $1 \operatorname{din} 4(25 \%)$ & - \\
\hline Nakajima J, 2008 [9] & $\begin{array}{l}5 \operatorname{din} 55 \\
(9 \%)\end{array}$ & $3-46$ luni & ARAch 3 din 13 (23\%) & 1 recurență $(20 \%)$ \\
\hline Sun X, 2011[12] & $\begin{array}{c}6 \operatorname{din} 125 \\
(4,8 \%)\end{array}$ & 1săpt. - 31 luni & ARAch $4 \operatorname{din} 22(18,1 \%)$ & 0 \\
\hline
\end{tabular}

* Numărul pacienților cu miastenie postoperatorie raportat la numărul timoamelor non-miastenice; ** Raportul dintre numărul pacienților miastenici cu titru crescut şi cel al pacienților care prezintă titru crescut preoperator; *** Numărul pacienților cu miastenie postoperatorie raportat la numărul timoamelor cu miastenie; $\Delta \mathrm{t}$ intervalul de timp între rezectie și apariția miasteniei gravis 
Această formă particulară de miastenie succede mai des forme invazive ale timoamelor. Evoli şi colab. [10] constată că 11 din cele 13 miastenii postoperatorii $(84,61 \%)$ au fost precedate de rezecția unor tumori invazive [10]. De remarcat este faptul că timoamele cu miastenie concomitentă au reprezentat $53,61 \%$ din leziunile invazive. $\mathrm{O}$ remarcă similară este făcută şi Li şi colab. [14]: 8 din 15 cazuri de miastenie postoperatorie $(53,33 \%)$ au apărut după rezecția unor timoame în stadiul II şi III. Kondo numără 6 din 8 miastenii postoperatorii ca fiind consecutive unor timoame în stadiile II-IV [3].

Intervalul de timp scurs între apariția miasteniei şi momentul rezecţiei timomului este variabil (Tabelul I): de la perioada postoperatorie imediată $[13,14]$ până la câteva luni sau câțiva ani $[6,9,10]$. Intervalul cel mai mare de timp în care au apărut fenomenele bolii autoimune este de 18 ani de la rezecția timomului. Sunt citate două astfel de cazuri unul cu [15] şi altul fără recidivă tumorală [7].

Din punctul de vedere al latenței fenomenelor autoimune, luând ca reper 6 luni scurse de la intervenție, Ito împarte miasteniile post-timectomie în miastenii precoce şi tardive [13].

Similar celorlalte forme de miastenie (miastenia cu s-au fără timom), mecanismul apariției bolii la aceşti pacienţi nu este cunoscut. Kuwata identifică trei ipoteze diferite: 1) recidiva sau metastazarea timomului, 2) exereza unor timoame cu forme infraclinice de miastenie şi 3) activarea postoperatorie a limfocitelor periferice [16].

Miastenia gravis a fost citată ca factor ce a evidențiat recurența sau metastazarea unor timoame non miastenice rezecate $[9,13,17]$. Ito şi colab. [13] remarcă faptul că multe din miasteniile aşa zis tardive au fost legate de recurența tumorală: 5 din 11 miastenii tardive au avut recăderi tumorale fapt neîntâlnit la cele 7 miastenii precoce. Evoli, studiind 207 timoame cu miastenie găseşte 13 cazuri de miastenii postoperatorii apărute [10]. Dintre acestea doar 3 (23\%) au fost asociate cu recurența tumorală [10]. Valori similare $(20 \%)$ sunt raportate şi în studiul lui Nakajima şi colab. [9]. Nici exereza unei recurențe a timomului nu exclude apariția miasteniei postoperatorii. Astfel, Tseng prezintă un pacient care la 35 de luni după rezecția unui timom B1 şi stadiul II Masaoka, este operat pentru o metastază pleurală dreaptă [18]. După alte 30 de luni dezvoltă fenomenele miasteniei gravis acesta fiind controlată prin tratament cu cortizon şi anticolinesterazice [18].

Ito şi colab. [13] consideră că miasteniile dezvoltate în primele 6 luni sunt expresia unor forme infraclinice de boală, nedepistate la momentul rezecției tumorale. Din cele 15 miastenii prezentate de Li, 4 sau manifestat imediat după terminarea intervenției chirurgicale, autorul atrăgând atenția asupra rolului favorizant al medicației curarizante folosite intraoperator [14]. Frecvența asocierii acestei evoluții postoperatorii imediate: 4 din cele 127 de timoame fără miastenie $(3,14 \%)$, nu are valori suficient de mari pentru a contraindica de principiu utilizarea curarizantelor în timpul rezecției timoamelor. Un alt factor incriminat în activarea acestor miastenii infraclinice ar fi aminogliocozidele folosite deseori în perioada postoperatorie [12].

În sprijinul mecanismului extra timic de producție a autoanticorpilor, majoritatea autorilor invocă două studii. A fost demonstrat faptul că celulele $T$ existente în timoame trec în sângele periferic, unde pot persista pentru mulți ani [19]. Prin persistența acestor celule s-ar crea condițiile secreției extra timice a autoanticorpilor. Acest mecanism este susţinut şi de evidențierea eliberării de către timoame în torentul sangvin de ,mature auto-antigenspecific T-cells" [20]. Triggerul declanşării acestor fenomene autoimune rămâne totuşi necunoscut.

A fost observată o corespondență între nivele crescute ale autoanticorpilor antireceptor de acetilcolină şi riscul apariţiei miasteniei postoperatorii. Sun şi colab. [12] remarcă faptul că 4 din cei 22 de pacienți care au prezentat aceşti anticorpi 
preoperator, au dezvoltat mai târziu $\mathrm{MG}$ $(18,1 \%)$. Valori similare raportează şi Nakajima (23\%) şi Kondo (25\%).

O importanța perdictivă mai mare se pare că $\mathrm{o}$ au autoanticorpii antifibră musculară striată. În studiul lui Ohta şi colab. [11], din 46 de timoame fără miastenie 18 au avut titruri crescute ale acestor autoanticorpi preoperator şi, din aceștia, $9(50 \%)$ au dezvoltat miastenie. Mai mult, din cei care au fost negativi la acest test, niciunul nu a prezentat boala postoperator [11].

Este cunoscut, dar totuşi controversat încă, rolul timectomiei în tratamentul miasteniei gravis. În cazul timoamelor, Masaoka afirmă că rezecția timusului şi a grăsimii mediastinale asociate extirpării unui timom micşorează rata recidivelor şi scade riscul apariţiei miasteniei postoperatorii [21]. Din păcate nu sunt prezentate şi argumente clinice cu privire la riscul miasteniei. Mai mult, sunt numeroase studii care infirmă existența unei legături dintre asocierea rezecției timusului şi a grăsimii mediastinului anterior şi riscul de apariţie a miasteniei postoperatorii. Observând 18 miastenii postoperatorii din 394 de timoame non-miastenice operate, Ito a calculat o rată de apariție a miasteniei de 2,8\% după timectomie şi de 3,9\% după timo-timectomie [13]. O observaţie similară face şi Nakajima care constată că în 4 din cele 5 miastenii postoperatorii s-a practicat timectomia extinsă [9]. Mai mult din cele 8 cazuri prezentate de Kondo, 2 au urmat după o timectomie extinsă şi 6 după timectomie [3]. Din cele 137 de cazuri în care s-a practicat doar exereza tumorii niciunul nu s-a complicat cu miastenie postoperatorie [3]. Dintr-un număr de 6 miastenii postoperatorii studiate de Sun, 3 au apărut după o timectomie extinsă şi 3 au sucedat o timotimectomie.

De observat că în niciun caz în care s-a efectuat doar rezecția timomului nu s-a constatat apariţia misteniei postoperatorii [12].

\section{CONCLUZII}

Remarcăm faptul că, deşi este o entitate rar întâlnită în practică, miastenia după timectomie trebuie luată în considerare în evoluția postoperatorie a pacienților cu timom. Dintre factorii predictivi ai acestei boli sunt: invazivitatea tumorii, titrul autoanticorpilor antifibră musculară striată şi cel al autoanticorpilor antireceptor de acetilcolină. Asocierea timectomiei sau a rezecției grăsimii mediastinale nu influențează riscul producerii acestei boli.

\section{CONFLICT DE INTERESE}

Autorii nu declară nici un conflict de interese.

\section{BIBLIOGRAFIE}

1. Vincent A, Palace J, Hilton-Jones D. Myasthenia gravis. Lancet. 2001; 357: 21222128.

2. Engels EA. Epidemiology of thymoma and associated malignancies. Thorac Oncol. 2010; 5(10 Suppl 4): S260-S265.

3. Kondo K, Monden Y. Myasthenia gravis appearing after thymectomy for thymoma. Eur J Cardiothorac Surg. 2005; 28(1): 22-25.

4. Fershtand JB, Shaw RR. Malignant tumor of the thymus gland, myasthenia gravis developing after removal. Ann Intern Med. 1951; 34: 1025-1035.

5. Green RA, Booth CB. The development of myasthenia gravis after removal of thymoma. Am J Med. 1958; 25(2): 293-302.

6. Kang SY, Lee JS, Choi JC, Kang JH. Myasthenia gravis appearing after thymectomy: a case report and review of the literature. J Clin Neurol. 2007; 3(3): 158-160.

7. Shaulov A, Rottenstreich M, Peleg H, Spiegel M, Shichman B, Argov Z.Myasthenia gravis appearing 18 years after resection of benign thymoma with subsequent limbic encephalitis. J Neurol Sci. 2012; 317(1-2): 146-147.

8. Namba T, Grunner NG, Grob D. Myasthenia gravis in patients with thymoma, with particular reference to onset after thymectomy. Medicine. 1978; 57: 411-433.

9. Nakajima J, Murakawa T, Fukami T, Sano A, Takamoto S, Ohtsu H. Postthymectomy myasthenia gravis: relationship with thymoma and antiacetylcholine receptor antibody. Ann Thorac Surg. 2008; 86(3): 941-945. 
10. Evoli A, Minisci C, Di Schino C, et al. Thymoma in patients with MG: characteristics and long-term outcome. Neurology. 2002; 59(12): 1844-1850.

11. Ohta M, Itoh M, Hara H, et al. Anti-skeletal muscle and anti-acetylcholine receptor antibodies in patients with thymoma without myasthenia gravis: relation to the onset of myasthenia gravis. Clin Chim Acta. 1991; 201(3): 201-205.

12. Sun XG, Wang YL, Liu YH, et al. Myasthenia gravis appearing after thymectomy. J Clin Neurosci. 2011; 18(1): 57-60

13. Ito M, Fujimura S, Monden $\mathrm{Y}$, et al. A retrospective group study on post-thymectomy myasthenia gravis. Nihon Kyobu Geka Gakkai Zasshi. 1992; 40(2): 189-193.

14. Li J, Zhang DC, Wang LJ, Zhang DW, Zhang RG. Myasthenia gravis occurring after resection of thymoma. Zhonghua Wai Ke Za Zhi. 2004; 42: 540-542.

15. Shinkai T, Saijo N, Yoshioka S, et al. Recurrence of thymoma with appearance of myasthenia gravis 18 years after surgery. Jpn J Clin Oncol. 1985; 15: 567-575.
16. Kuwata T, Iwata T, Iwanami T. Postthymectomy myasthenia gravis with an episode of Osserman stage III. JSCR. 2012; 5: 3.

17. Denayer MA, Rao KR, Wirz D, McNally D. Hepatic metastatic thymoma and myasthenia gravis twenty-two years after the apparent cure of an invasive thymoma. A case report and review of the literature. J Neurol Sci. 1986; 76: 23-30.

18. Tseng YL, Chang JM, Shu IL, Wu MH. Myasthenia gravis developed 30 months after resection of recurrent thymoma. Eur $J$ Cardiothorac Surg. 2006; 29(2): 268-269.

19. Buckley C, Douek D, Newsom-Davis J, Vincent A, Willcox N. Mature, long-lived CD4+ and CD8+ T cells are generated by the thymoma in myasthenia gravis. Ann Neurol. 2000; 50: 64-72.

20. Hoffacker V, Schultz A, Tiesinga JJ, et al. Thymomas after the T-cell subset composition in the blood: a potential mechanism for thymoma associated autoimmune disease. Blood. 2000; 96: 3872-3879.

21. Masaoka A. Staging system of thymoma. $J$ Thorac Oncol. 2010; 5(10 Suppl 4): S304S312. 